\title{
Ellipsis
}

2021

\section{Watching through the Glass Coffin of the Gallagh Man}

Lauren Berman

Follow this and additional works at: https://scholarworks.uno.edu/ellipsis

\section{Recommended Citation}

Berman, Lauren (2021) "Watching through the Glass Coffin of the Gallagh Man," Ellipsis: Vol. 46 , Article 2. DOI: https://doi.org/10.46428/ejail.46.02

Available at: https://scholarworks.uno.edu/ellipsis/vol46/iss1/2

This Poetry is brought to you for free and open access by the Department of English and Foreign Languages at ScholarWorks@UNO. It has been accepted for inclusion in Ellipsis by an authorized editor of ScholarWorks@UNO. For more information, please contact scholarworks@uno.edu. 


\section{Vassar Miller Poetry Award \\ Honorable Mention}

\section{Watching Through the Glass Coffin of the Gallagh Man by Lauren Berman}

Fetal, crossed arms at his chest, face crushed, turned outwards, his teeth settle as sediment at the back of his throat.

I sit here my eyes trapped

in the leather of his skin, how it falls back and twists fraying from his bones.

Like bark, he morphs now a tree elemental in a glass box.

His death a sacrifice to shift the season to spring. All our faces like stars bore through the folds in his flesh. 